\title{
THE BOUNDARIES OF LANGUAGE AND GENDER REVISITED: PERFORMING GENDER IN SOCIAL NETWORKS
}

\author{
Antonio García Gómez y Fátima Garrido Pozo, Universidad de Alcalá ${ }^{1}$ \\ Email: antonio.garciag@uah.es
}

\begin{abstract}
Social networks have been evolving throughout time not just as a tool to socialize or interact, but as a fundamental system that helps people develop their lives. Among social network users, adolescents are, without any doubt, those who are more dependent on technology in general terms and social media in particular. They not only use it to connect to each other, but also to update and to evaluate what they hear, read and do both on- and offline. This research uses Facebook posts from British and Spanish male and female teenagers in order to explore these teenagers' practices of social networking. More precisely, the main aim of the current study is not only to analyse similarities and differences in the ways male and female teenagers communicate online, but also to uncover the different linguistic strategies they use to relate to others. The analysis gives evidence that there is a fine line in the use of positive and negative politeness strategies according to gender when negotiating conversational topics online.

Keywords: Computer Mediated Communication, Performativity, Female and Male Conversational Topics, and Politeness Strategies.
\end{abstract}

Título en español: "Revisión de las fronteras entre Lengua y Género: La performatividad de género en redes sociales".

Resumen: Las redes sociales han evolucionado a lo largo del tiempo. De este modo, han dejado de ser utilizadas exclusivamente como una herramienta de socialización e interacción y han pasado a entenderse como un sistema fundamental que ayuda a las personas a desarrollar sus propias vidas. Entre los usuarios de redes sociales, los adolescentes son, sin lugar a dudas, aquellos que son más dependientes de las nuevas tecnologías en general y de las redes sociales en concreto. No sólo las utilizan para estar en contacto con otras personas, sino que también las usan para estar al día y evaluar aquello que oyen, leen y hacen tanto en línea como fuera de línea. La presente investigación utiliza mensajes publicados en el muro de Facebook por adolescentes británic@s y español@s con el objeto de explorar sus prácticas en esta red social. En concreto, este estudio tiene como objetivo no sólo analizar las diferencias y similitudes en la(s) forma(s) que est@s adolescentes se comunican en línea, sino también descubrir las diferentes estrategias linguiísticas que usan para relacionarse con otros usuarios. El análisis prueba que hay una delgada línea en el uso de las estrategias de cortesía positiva y negativa en lo que respecta al género de los usuarios mientras tratan distintos temas en línea.

Palabras clave: Comunicación mediada por ordenador, performatividad, temas conversacionales femeninos y masculinos y estrategías de cortesía.

Date of reception: 25 September 2015

Date of acceptance: 28 October 2015 


\section{INTRODUCTION}

Third Wave Feminist Linguistics relies on the work of Judith Butler, particularly the notion of performativity (Butler, 1990). Linguists such as Eckert (1989 and 2000), Cameron (1995), Crawford (1995), Swann (2002), Coates (2004), and Speer (2005) among many others, abandoned the idea that gender not only pre-existed the interaction, but also had an effect on the way the interaction developed. In doing so, Third Wave feminists conceptualized gender as a process rather than a state and cast light on the way that participants bring about their gendered identity in conversation (Mills, 2003). In addition, these researchers postulate that if women are not a homogenous group, there is no point in addressing women's and men's language as necessarily different. Therefore, these studies move towards understanding the way that different contexts shape interaction.

Interestingly and contrary to this line of thought, the idea of addressing a distinctive set of linguistic strategies in interaction for each gender is again gaining momentum in the literature. Esopo (2010), for instance, claims that the variance in style and phonetic features can be considered manifestations of the social position of each gender and, therefore, give evidence of a speaker's sexual identity. Sanz (2012) also argues in favour of maintaining a distinctive set of conversational features for each gender. Women (a) tend to use both more polite and formal phrases than men; (b) ask more questions and express more exclamations and effective vocatives; and (c) prefer small group discussions given that topics tend to be covered from a personal perspective. According to Sanz (2012), the conversation of men can be considered more direct and cold, because they focus on supporting the representative function of language. They are interested in facts, data and evaluation. They do not give many compliments or praise because they have assumed that they will be received with suspicion and may harbor ulterior motives (Maíz-Arévalo, 2010a and 2012a).

Indebted to these Third Wave feminist analyses, we are interested in shedding light on the way(s) British and Spanish teenagers perform their gendered identity when socialising with their Facebook friends. More specifically, the present study pays attention to the use of politeness strategies (Brown and Levinson, 1987) used in Facebook interaction in order to achieve specific purposes. In order to do so, we will start by analyzing the sort of topics British and Spanish teenagers discuss on their Facebook walls in order to explore whether or not there seems to be a connection between topics and gender. This exploration will pave the way for answering the two questions which guide the current research: "What sort of politeness strategies do British and Spanish female and male teenagers tend to exploit in social networking messages?" and "Can these politeness strategies be said to be gender-specific?"

In what follows, section 1 presents an overview of existing research into gender and language and performance. Section 2 deals with the methodology applied to the study. Section 3 offers an approach to the study of topicality and politeness strategies in an online context. Finally, section 4 draws the most important conclusions from the analysis. 


\section{THEORETICAL FRAMEWORK}

\subsection{Gender, language and performance: an overview of the literature}

In accordance with Coates (2004: 26), it was not until the seventies, linguistics started concerning itself with the existing gender-language relationship. She states that there are three basic reasons for exploring that relationship: The first two reasons are the sociolinguistic record in dialectology and in linguistics and the third one is related to the changes of women's position in our society. Following this line of thought, Coates (2004: 24) suggests that the role of male gender has always been very strong and influential insofar as the man was the person who takes up the heart of the history.

In the seventies, Lakoff (1975) changed linguists' mind with her work Language of Women's place. From that moment on, a flourishing and ground-breaking wealth of literature has been devoted to dealing with gender from different approaches such as deficit, command, difference and dynamism or social construction (Labov, 1972; Johnson and Meinhoff, 1997; Coates, 2004; García-Gómez, 2013 and 2014, among many others). Although the dynamic approach has become more popular recently as new research emerges (Peck, 2006), the other approaches have also coexisted quite harmoniously over the last few years (García-Gómez, 2010). In particular, the deficit approach was the first standpoint which was developed based upon the work of Robin Lakoff. Her book Language of Women's Place is often credited with establishing language as an object of study in sociolinguistics. She launched new ideas about women's language that are ordinary today, taking into account class, power, and social justice in addition to gender. Her proposal was that women's language can be very different from men's. For instance, the exploitation of hedges, empty adjectives, super-polite forms, apologies, tag- questions, prestige grammar and clear pronunciation, use of indirect style in women's speech was considered a mark of being weak and deficient.

In the eighties, West and Zimmerman (1983) perceived that the female sex was an oppressed group where the linguistic differences between both sexes were interpreted in terms of masculine domination and feminine subordination. More specifically, West and Zimmerman suggested that applying power implies applying gender. However, it was not until the end of the eighties that Humm (1989) spread the view of difference. This approach explained the idea that men and women came from different cultures and the advantage of it was that the women' speech had to be examined outside the oppression environment. Indebted to Humm, Tannen's adopted this approach in her 1990 book 'You just don't understand'. She attempted to explain why men and women seek independence and intimacy from conversations. Tannen claimed that men usually speak in public even if they do not know or understand much about a subject, while women tend to listen more. As she suggested, these are patterns that begin in childhood and have contradictory consequences. Men make use of the language of conflict to create connections; whereas women use the language of connection to create conflict. Tannen further explains (1990: 77):

Women and men are inclined to understand each other in terms of their own styles because we assume we all live in the same world. If the genders would keep this in mind and adjust accordingly much discord between them could be averted. 
As García-Gómez (2010) points out, Tannen's approach can be connected to Butler's (1990) analysis of gender development and identity as a continuous undertaking in order to understand the limits that define our gendered identity. Furthermore, he adds that one of the Butler's dilemmas confronting women is the question of whether gender is an expression of what one is or something one does. The influence of new media technologies on gender socialisation and gender performativity has attracted the attention of many researchers in recent years (Ringrose et al., 2013). More specifically, elements of this research have concentrated on the forms that gendered discourses can take and the ways in which gender is constructed discursively and performed (García-Gómez 2008a, 2008b), while others demonstrate that women and men alike make choices in how they express themselves in discourses and how they perform the gender roles that they choose (Cammack and Kalmbach Phillips, 2002).

\subsection{Gender and Politeness}

Given that the focus of our research is the use of politeness strategies in social networks, it is necessary to briefly develop the theories related to politeness and gender. Politeness theory, first formulated in 1978 by Brown and Levinson, accounts for the redressing of the affronts to face posed by face-threatening acts to addressees (Foley, 1997). In relating politeness to gender, Holmes (1995) argues that politeness strategies have also been shown to vary according to gender, showing differences in the use of politeness strategies between men and women. Her work reveals that the relationship between sex, politeness and language is a complex one. The fact that women are more polite than men depends upon what we mean by "polite" as well as which women and men are being compared.

In Gender and Politeness (2003), Mill argues the importance of context in order to determine whether what someone says may be interpreted as polite or not. Following this line of thought, Cameron (1998) and Eelen (2001) suggest that an utterance may be considered to be polite or impolite according to three main variables: 1) who is saying what; 2) to whom; and 3) for what purpose. This "community of practice" view of politeness and gender is shared by many other linguists (Scollon, 2001; Locher and Watts, 2005). For instance, Christie (2002) claims, in an interesting study of politeness and gender in parliamentary debate in the UK, that a good parliamentary speaker is expected to insult other speakers no matter their gender.

Several theories of politeness have been proposed (Leech, 1983; Fraser, 1990); however, the most fully elaborated work on linguistic politeness is Brown and Levinson's model (1978 and revisited in 1987). In a spirit of exploration rather than ex cathedra pronouncement, the study of linguistic politeness in Facebook comments made by British and Spanish male and female teenagers presented here does not attempt to contradict the universal character ascribed to Brown and Levinson's framework, but to develop and improve their valuable material. In brief, Brown and Levinson devoted themselves to the study of the ways in which people use language in the service of face management (Holtgraves, 2002). In their account, as García-Gómez (2006) suggests, face: 
comes in two varieties: positive face or the person's need to be well thought of; and negative face or the person's dislike for being imposed on by others. Thus, there appears to be a mutual self-interest in any interaction, requiring that conversational participants maintain both their own face and their interlocutors' face. In the continual interactive balancing of one's own and the other's face, people incorporate into the structure of an utterance positive and negative politeness strategies to diminish these potential threats (García-Gómez, 2006: 147).

Furthermore, Brown and Levinson (1987) conceived politeness as a speaker's orientation toward the listener or listener's face, and they define it as a public image that every person claims for himself/herself. This image can be positive (need for each person of not being bothered) or negative (need that people's needs are shared by others). Persuasions and offers impose a menacing aspect upon the image of the speaker. Besides speech acts that affect the speaker, there are others which concern the listener, such as promises and apologies. Brown and Levinson (1987) state that threats to the interlocutor's image can be minimized by means of two politeness strategies. The first one consists of giving a clear statement. Another possibility lies in performing indirect speech acts in which the speaker's intention becomes ambiguous, such as rhetorical questions, allusions, ironies and generalizations. The use of either communication strategy is determined by three sociological factors: the degree of authority that the speaker has on the listener, the social distance among the participants and the level of insistence that an act has in a particular culture.

\section{CORPUS AND PARTICIPANTS}

This research attempts to encompass two different epistemological frameworks. On the one hand, this study reports the results of a qualitative, discursive and constructivist analysis of constructs of normative femininity/masculinity and the identity work of teenagers as they write comments on their friends' Facebook walls on different topics. On the other hand, a quantitative framework is used in order to make and justify statements about differences between British and Spanish teenagers' use of politeness strategies.

The social network corpus consists of 519 messages written in Facebook by 31 British participants (16 females and 15 males) and 29 Spanish participants (15 females and 14 males).A general assumption in language and gender studies is that even in one society, e.g. Britain or Spain, men and women cannot be discussed as if they form a single homogeneous category. In order to provide a homogeneous sample, the data selected come from a specific subsection of the male and female population: teenage heterosexual Facebookers. More precisely, four main dimensions of identity that affect the way that the gendered selves are presented were considered: gender, age, race and social class. All teen males and females are white, middle-class and range from fourteen to seventeen years of age and are secondary-school students. Participants were relatives' and friends' sons and daughters. It must be said that both parents and teenagers were first contacted with explanations of the research objectives in simple terms and were encouraged to take part in the study. All parents signed the informed consent for research.

At the beginning stages of this research project, the intention of studying teenagers' personal posted posed a moral question given the age of these teenagers: "What are the 
potential ethical implications of analysing these posts?". Although all the posts selected were "public" documents ${ }^{2}$ and, therefore, no consent for their use in research were needed, we could not deny our ethical responsibility as researchers. Two decisions were made to solve this moral dilemma. The first decision had to do with the anonymity procedures and the second one was concerned with our ethical position:

- Anonymity procedures. All the posts selected guarantee the privacy of their writers as they were selected on the basis of including no personal pictures or real names. All posts selected for analysis did not reveal the author's real name. In this way, participants cannot be identified and their anonymity is guaranteed.

- Analytical and ethical position. In line with DiMaggio et al. (2001) and Meyer (2003), our focus is on social networking writing's implications for social change. Even though posts are an opportunity for reflection and for identity work, we decided to adopt a social constructionist orientation. Consistent with this orientation, posts cannot be seen as a straight forward reflection of the behaviour or experience of the writers, rather the post provides a context in which to engage in relationship talk, and tell us something about the cultural norms and possibly community of practice norms - in this peer group of young men and young women that post comments on their Facebook wall and their friends, that are attended to or challenged.

\section{LANGUAGE AND GENDER IN SOCIAL NETWORKS}

\subsection{A gender-based topic analysis: Uncovering an evaluative function of topicality}

Analysis of the data gives evidence that traditional stereotypes attributed to girls and boys seem to be present in these male and female teenagers' conversational topics online. Still one may wonder why conversations are so different from females to males. Ríos González (2007) answers this question herself:

Society and even family have greatly influenced in the way people talk and think about men and women. This social representation, which is passed down since childhood, is one that the individual is forced to satisfy behaving according to their gender as society expects to do (Ríos González, 2007: 153).

The analysis of the topics discussed shows that there are different degrees of self-involvement that are connected with the nature of the topics posted on their Facebook walls. Table 1 shows the mean number of topics discussed by these male teenagers.

\footnotetext{
2 All of the posts selected were taken from open-access walls; that is, these users voluntarily had decided not to restrict the access to their profile and wall. 
Table 1: Topics discussed by British and Spanish male teenagers in the corpus of data

\begin{tabular}{|l|c|c|}
\hline \multirow{2}{*}{ Topics } & All items $(\mathrm{n}=126)$ & $(\mathrm{n}=131)$ \\
\cline { 2 - 3 } & British teens & Spanish teens \\
\hline Love relationships & $10.2 \%$ & $12.4 \%$ \\
\hline $\begin{array}{l}\text { Expression of feelings and } \\
\text { thoughts }\end{array}$ & $5.6 \%$ & $7.1 \%$ \\
\hline Gossips / rumour spreading & $1.1 \%$ & $2.3 \%$ \\
\hline $\begin{array}{l}\text { Experiences at home with } \\
\text { relatives }\end{array}$ & $1.2 \%$ & $5.9 \%$ \\
\hline $\begin{array}{l}\text { Experiences at school with } \\
\text { a teacher }\end{array}$ & $3.8 \%$ & $34.7 \%$ \\
\hline $\begin{array}{l}\text { Interest / hobbies (e.g. } \\
\text { football) }\end{array}$ & $37.3 \%$ & $32.8 \%$ \\
\hline Sex & $33.5 \%$ & $3.3 \%$ \\
\hline Other issues & $6.3 \%$ & \\
\hline
\end{tabular}

With regard to the topics found in the corpus of data, table 1 shows that the most frequent topics are: interests/hobbies and sex. In fact, most of the comments made by the male teenagers had to do with sports (i.e. interest and hobbies). More specifically, most of their comments were related to football where young men tend to comment on every single minute of a match, results, opinions about football players and trainers. Of particular interest here is the fact that there is an evaluative function behind this topic as these young men criticise the opposing team, make use of positive language to talk about "their" team, justify things that the supported team could not do well and use jargon to demonstrate their knowledge about the topic (Eggins and Slade, 1997). The following examples illustrate this point:

(1) Male, 16 years old, Spanish

"¿Cristiano está prohibido expulsarlo? O yo no tengo ni puta idea de fútbol, que puto robo".

"Can Cristiano not be sent off?? Or I'm fucking clueless about football, that is a fucking robbery".

(2) Male, 15 years old, British

"Ashley Cole and John Terry. They can't be that stupid, surely? you stupid plastic Chelsea cunts.".

As shown in the examples (1-2), these young men, while commenting on football, use, on the one hand, evaluative language as the one holds that Cristiano should be put out of the 
game and the latter subject uses jargon related to the field, inferring that Chelsea's Ashley Cole and John Terry have ruined their reputation and insult both these players and their supporters. In addition, these young men discuss other sports; however, a similar linguistic behavior is observed. Let us consider the following examples:

(3) Male, 14 years old, British "Predosa wins the GP in France! Great Dani!"

(4) Male, 14 years old, Spanish

"Nadal es un dios!!!!!"”

"Nadal is a God!!!!!"

The first comment (3) is focused on GP motor races, specifically, "Predosa" (an athlete) and his victory. The second comment (4) shows this young man's admiration of the Spanish tennis player.

The second most common topic in both British and Spanish male teenagers' posts is sex. These young men tend to acquire the status via their amorous conquests. As some other recent studies suggest the data seems to reflect that there is a double sexual standard (Ringrose et al., 2013; García-Gómez, 2014). Examples 5 and 6 illustrate this affirmation:

(5) Male, 17 years old, Spanish

"Sé que te lo he dicho muchas veces, pero es que no es normal como está la biblioteca de tías en estas fechas. Cualquier día hago una locura"

"I know I've said this many times, but it's not normal how many chicks there are in the library these days. One day I'm gonna do something crazy."

(6) Male, 16 years old, British

"I know she's a whore, but she knows when Im... on heat J and she definitely knows how to satisfy a man. My trouser department is all hers"

As these examples show, it is considered acceptable that men are studs for having casual sex or sex with lots of partners, but women are sluts and depicted as sluts. In other words, women seem to be judged more harshly than men for engaging in the same behaviors (Ringrose et al., 2013). Facebook friends of participants commonly encouraged them to do as they pleased and showed their admiration. Comments such as "U rock" or "U $\mathrm{r}$ my hero, man."

As part of the commentary on their sex lives, these male teenagers seem to enjoy talking about women. Conversations are usually examples of sweeping generalisations in which these teenagers evaluate a female's physical appearance in general and their sex partner in particular. The key issue here is that the pattern still revolves around hetero-normative behaviour (Butler, 1990): the standard is given by men, and women have the obligation to uphold that standard in order to satisfy men's needs (García-Gómez, 2010). Look at the following examples:

(7) Male, 16 years old, British

"It should be prohibited to present hot blonde girls in the Eurovision contest" 
(8) Male, 17 years old, Spanish

"Todas las mujeres son iguales. No se conforman con un buen polvo siempre necesitan un anillo de compromiso".

"All women are the same. Having a good shag is not enough, they all need an engagement ring”

(9) Male, 15 years old, British

"She pisses me off. Doesn't she know her birth certificate is an apology from the condom factory. LOL"

In contrast to this preference in both British and Spanish male topics, women shows a different preference as far as topics are concerned. Female teenagers still seem to focus on the personal and the private rather than on the global and the public (Eggins and Slade, 1997). With regard to the treatment of information, detailed analysis shows a tendency, in almost any topic, to find a pejorative judgement of an absent other who was not supposed to read the contents of the comment. In contrast to male teenagers, these female teenagers write extensively about personal matters and feelings. Interestingly, a great attention is paid to love relationships and narrations of conversations kept at school with some other classmates. Table 2 shows the mean number of topics discussed by these female teenagers.

Table 2: Topics discussed by British and Spanish female teenagers in the corpus of data

\begin{tabular}{|l|c|c|}
\hline \multirow{2}{*}{ Topics } & All items $(\mathrm{n}=135)$ & $(\mathrm{n}=127)$ \\
\cline { 2 - 3 } & British teens & Spanish teens \\
\hline Love relationships & $35.2 \%$ & $38.4 \%$ \\
\hline $\begin{array}{l}\text { Expression of feelings and } \\
\text { thoughts }\end{array}$ & $17.3 \%$ & $15.1 \%$ \\
\hline Gossips / rumour spreading & $16.7 \%$ & $19.5 \%$ \\
\hline $\begin{array}{l}\text { Experiences at home with } \\
\text { relatives }\end{array}$ & $11.2 \%$ & $9.3 \%$ \\
\hline $\begin{array}{l}\text { Experiences at school with } \\
\text { a teacher }\end{array}$ & $10.9 \%$ & $6.4 \%$ \\
\hline Sex & $3.5 \%$ & $3.8 \%$ \\
\hline Other issues & $5.2 \%$ & $3.5 \%$ \\
\hline
\end{tabular}

Unlike young men, the most recurrent topics are love relationships and the expression of feelings and thoughts. Facebook clearly provides an open and potentially anonymous venue to explore early twenty-first century relationships (Janssen and Murachver, 2004). More precisely, these female Facebookers explore shared interests and find a medium 
through which they can express themselves freely and, as García-Gómez (2008a) claims, female teenagers devote much of their writing to sharing their love-lives with others. Examples make it possible to argue that these young women are invited to define their sense of power and desire almost exclusively in terms of dominant male narratives. Take the following examples:

(10) Female, 16 years old, British

"I love him SOOOOOO much. I know we were meant for each since the first moment I saw him. He is one of a kind. He's eternally on my mind"

(11) Female, 16 years old, Spanish

"No puede quererle más. Es mazo mono.".

"I love him more than words can say. He's so cute.

Interestingly, when these female teenagers comment on their love relationships they reaffirm traditional love myths and, in doing so, they define their identities as subordinate to their boyfriends' (Giroux, 2005). Although gossip has been denigrated as "idle talk" (Eggins and Slade, 1997), these female teenagers tend to write on their friends' Facebook walls about an absent other. In doing so, they share their values, negotiate reality and arrive at a shared understanding (Coates, 2004). This fact can be seen insofar as these Facebook posts are the ones that are more commented-upon by other friends. This underscores the idea that this kind of talk is collaborative and is jointly constructed by all participants.

(12) Female, 15 years old, British

"She's not that pretty! Don't know what Mark can see in her... well I can imagine what she does on her knees"

(13) Female, 17 years old, Spanish

"La muy guarra no me dijo que el vestido estaba de rebajas para que no me lo comprara. Lo que no sabe es que ella es GORDA y FEA"

"She's a whore. She didn't tell me the dress was on sale so that I wouldn't buy it. What she doesn't know is that she is FAT and UGLY"

Analysis of the examples shows that these utterances perform an evaluative function insofar as these teens' gossip revolves around the negative appraisal of an absent other's physical appearance. As part of adolescence, they seem to suffer from low self-esteem and put others down in an attempt to boost themselves up, as illustrated in the following examples:

(14) Female, 17 years old, British

"Don't know how she's not pregnant. Everybody knows what she does. I'm not a saint either but I'm not like her. I decide when, how and with whom"

(15) Female, 15 years old, Spanish

"Es más fea que un pie. Se creerá guapa pero yo no distingo entre su cara y su culo. Yo no seré gran cosa pero ella".

"She is ugly as hell. She thinks she's beautiful but I can't see any difference between her 
face and her arse. I'm not very pretty but she is...".

All in all, these female teenagers use gossip as an in-group strategy. The Internet in general and social networks in particular have become a powerful, yet a dangerous, tool to cyber-bully classmates. These girls do not seem to be aware that they talk about others behind their backs in an attempt to be "a part of the group", but, in doing so, gossip inevitably causes someone else to suffer the frustration of being excluded (Dellasega and Nixon, 2003).

Finally, these female teenagers also talk about boys in general and their partners in particular. The way this topic is addressed by these female teenagers is dramatically different from the way we explained above. Once again, they comment on boys in an attempt to connect to each other, to establish a bond with each other. This is a significant issue since it informs their sense of feminine intimacy. The topic is more common at this age, because it is in this moment when these young women start to confess secrets to their best friends (e.g. who they are in love with, etc.) While these young men's comments cast women in a negative light (i.e. depicting women as sex objects); young women orientate the issue of men towards the admiration and respect for their couples. What emerges from this analysis is the perpetuation of patriarchal traditional patterns in which these young women feel they are dependent on men (García-Gómez, 2010). Example (16) shows how this young woman expresses her admiration; whereas example (17) illustrates how this young man describes a female friend of his:

(16) Female, 17 years old, Spanish

"Quiero felicitar a @diosdj26 que es el mejor y el que más quiero, gracias por estos 2 años (y los que nos quedan) te amo cariño."

"Congratulations to @ diosdj26who is the best and the one I love the most, thanks for these two years (and the ones that are coming) I love you honey."

(17) Male, 16 years old, Spanish

"Como está la Sandra, a esa le hacía yo un par de favores sin pensarlo."

"Sandra is very hot, I'd fuck her without a doubt."

The study seems to reveal that topics are, therefore, conditioned by society and tradition. The preferences of topics for each gender show the cultural and stereotype role that society experiments in the formation of both male and female identities.

\subsection{Teenagers' exploitation of politeness strategies: Is there a gender-specific use?}

For the study's purposes, the two most important topics selected facilitate analysis of these male and female teenagers' exploitation of politeness strategies: interest/hobbies and sex on the one hand, and love relationships and gossip on the other. Given that participants are defined as holding the same power, none of them are, initially, expected to exert power over the other or are allowed to impose a particular course of action. This gives strong support to the hypothesised connection between the male and female use of politeness strategies and whether relations in social networks are the result of purely individual motivation and/ or generated by a particular social configuration of boyhood/girlhood. 
Detailed analysis of the data makes it possible to argue that online communication plays a critical role in defining and shaping emotional and interpersonal processes through the occurrence of interaction patterns. More specifically, close examination of the data supports the following hypothesis: autonomy and affiliation are the two fundamental dimensions underlying the interpersonal relationship established in all of the Facebook comments. Consider the following examples:

(18) Female, 15 years old, Spanish "Venga, cuéntame que tál con tu novio... J"

"Come on, tell me about your boyfriend...J"

(19) Female, 17 years old, British

'You know I love you to bits, but I must ask you... Are you sure he's the right guy? J

(20) Male, 17 years old, Spanish "Acaso soy el único que se da cuenta de que Ronaldo es un paquete???? J" "Am I the only who's realized that Ronaldo is useless???? J"

(21) Male, 15 years old, British

"Do you still want to spend the evening with the silliest boy in Manchester? We can have a drink, go to the cinema, walk around...whenever you want! J”

These four examples (18-21) are representative of the type of the politeness strategies both British and Spanish female and male speakers make use of when commenting on their friends' Facebook walls. Both female and male participants claim common ground with their friends by seeking agreement. These examples also show how both male and female speakers want the listener to feel good in an attempt to achieve their respective discursive goals (i.e. get a piece of personal information from her friend (18); make her friend think about her relationship (19); get support from friends that agree with him (20); and get a date (21). Note the use of the smiling emoticons which minimizes any possible face threatening act. The analysis provides evidence that the two relational dimensions of autonomy and affiliation function simultaneously in every information exchange that takes place when posting on Facebook. In this context, British and Spanish female and male teenagers' face behaviours appear to be associated with individuals' sensitivity toward the reputations of others and themselves, and toward the projected images that each party wishes to have validated in the social interaction with the other.

The following table shows the different positive and negative politeness strategies and frequency of each pragmatic meaning of utterances: 
Table 3. Positive and negative politeness strategies in online conversational topics

\begin{tabular}{|l|c|c|c|c|}
\hline \multirow{2}{*}{\multicolumn{2}{|c}{ Positive politeness strategies }} & \multicolumn{2}{c|}{ British corpus } & \multicolumn{2}{c|}{ Spanish corpus } \\
\cline { 2 - 5 } & \multicolumn{2}{|c|}{ Female Male } & \multicolumn{2}{c|}{ Female Male } \\
\cline { 2 - 5 } & $\mathrm{n} .349$ & $\mathrm{n} .317$ & $\mathrm{n} .368$ & $\mathrm{n} .336$ \\
\hline Attend to H's interests, needs, wants & $33 \%$ & $32 \%$ & $35 \%$ & $38 \%$ \\
\hline Use solidarity in-group identity markers & $27 \%$ & $34 \%$ & $24 \%$ & $26 \%$ \\
\hline $\begin{array}{l}\text { Include both speaker (S) and hearer (H) in } \\
\text { activity }\end{array}$ & $13 \%$ & $21 \%$ & $11 \%$ & $19 \%$ \\
\hline Exaggerate interest in H and his interests & $19 \%$ & $8 \%$ & $26 \%$ & $15 \%$ \\
\hline Avoid disagreement & $8 \%$ & $5 \%$ & $4 \%$ & $2 \%$ \\
\hline Negative politeness strategies & $\mathrm{n} .37$ & $\mathrm{n} .273$ & $\mathrm{n} .14$ & $\mathrm{n} .311$ \\
\hline Be indirect & $49 \%$ & $33 \%$ & $34 \%$ & $15 \%$ \\
\hline Use hedges or questions & $24 \%$ & $8 \%$ & $29 \%$ & $12 \%$ \\
\hline Minimize the imposition & $27 \%$ & $59 \%$ & $37 \%$ & $73 \%$ \\
\hline
\end{tabular}

In addition to this, corpus data inspection reveals that there seems to be a direct relationship between gender and a particular use of politeness strategies. The study of the corpus has shown that both men and women use positive politeness strategies when commenting on the aforementioned topics. Although sociolinguistic research points out that women tend to use more positive politeness strategies than men in analogous situations (Pilkington, 1998), inspection of the data shows that there is no significant difference in the exploitation of positive politeness strategies when commenting on their (fe)male friend's walls about the four content areas under analysis (i.e. interests/hobbies and sex and love relationships and gossip). The evaluative function performed by utterances is supported by a careful exploitation of Politeness Strategies which aim to claim common ground with their Facebook (fe)male friends, by indicating they belong to the same set of people, who share specific wants, including goals and socially acceptable values. Consider the following examples:

(22) Female, 16 years old, Spanish

"Ya sabes que no soy una cotilla. Sólo me preocupo por ti. Sé por lo que estás pasando por las dos somos iguales. Somos amigas y eso es lo importante"

"You know I'm not a gossip girl. I'm just worried about you. I know what you're going through because we do see things in the same way. We're friends and that's what matters"

(23) Female, 16 years old, British

"She's a filthy little whore. Fortunately everybody knows she's not our friend. We are not like her"

(24) Male, 15 years old, Spanish

"Eres el mejor tío. ¡qué haría yo sin ti! Casillas FOREVER" 
"You're the best, man. What would I do without you! Casillas FOREVER"

(25) Male, 16 years old, British

"You know I admire you. You're my hero. Five lays, two girls LOL"

The most common manifestations of positive politeness strategies in the corpus of data are compliments. Interestingly, research suggests that women pay more compliments than men (Holmes, 1998; Johnson and Roen, 1992); however, detailed analysis of the corpus reveal that both British and Spanish male and female teenagers compliment their friends online. This may be due to the fact that it is easier to compliment other people online as the addressee is not face to face with their addresser. We here understand compliments to be clearly evaluative acts since they serve the speaker to stress the positive appraisal of the addressee (Holmes, 1986; Knapp et al., 1984; Wolfson, 1983, Maíz Arévalo 2010b and $2012 \mathrm{~b}$, among many others). These teenagers' compliments aim to encode their feelings of admiration towards others. Analysis of the female compliments shows there are two main groups: (i) direct positive appraisal of their male and female friends' appearance and/ or personality (26-27); and (ii) direct positive appraisal of their male and female friends' possessions (28-29), as illustrated in these examples:

(26) Female, 17 years old, Spanish "¡Qué guapísimas estás!! Como se nota que estás enamorada J” "How pretty you are! It's pretty obvious you're in love J"

(27) Female, 17 years old, British "U r so sweet! That's why I love you SO much"

(28) Female, 15 years old, Spanish "¡Qué pelazo tienes!!" "What beautiful hair you've got!"

(29) Female, 17 years old, British "What a nice boyfriend you've got!"

Although British and Spanish male teenagers also compliment their female and male friends, a cultural-relativist distinction can be drawn. Spanish male teenagers positively evaluate both their male and female friends' appearance and/or personality (30); and possessions (31); whereas British male teenagers only positively evaluate their female friends' appearance, personality and/or possessions (32) and their male friends' personality (33), as evidenced in the following examples:

(30) Male, 16 years old, Spanish "¡Qué abdominales, guapetón!! Estás cuadrado tio"

"Fabulous abs, pretty boy!! You're hefty, man"

(31) Male, 17 years old, Spanish

"Zapatos chulos tienes. A ver cuándo me los prestas" 
"Nice shoes! When can I borrow them?"

(32) Male, 15 years old, British

"You're gorgeous!"

(33) Female, 17 years old, British

"Lad, you're my hero. No-one but you can do it this way!”

By complimenting others, these teenagers evaluate in-group behaviour by enhancing the positivity of the self-concept of the person who is being complimented. In particular, these British and Spanish male and female teenagers have their say and express their positive emotions by claiming common ground and trying to affiliate with significant others (i.e. their friends). The exploitation of positive politeness helps these teenagers form up the norms of the group and differentiate in-group members by appraising positively and publicly something one of these friends said or did.

Few instances of negative politeness strategies were identified in the corpus of data. Initially, one may think that the absence of this linguistic strategy has to do with the close relationship these young people have where there seems to be no need to emphasize avoidance of imposition on the hearer. However, a more detailed analysis of all of the instances found reveal that British and Spanish female teenagers exploited negative politeness strategies only when posting comments on their love relationships and always in an attempt to justify why they were not following their friends' piece of advice. This behaviour is present in following examples:

(34) Female, 16 years old, Spanish

"No sé, quizá llevéis razón, pero es que no sé quiero ver qué me dice cuando le vea hoy. Me entendéis, ¿verdad?”

"I don't know, perhaps you're right, but the thing is that I want to hear what he has to say. That makes sense, right?"

(35) Female, 16 years old, British

"Do me a favour, will you? Don't tell my parents I'm dating John today"

Even though research suggests that men are said to avoid apologising or softening criticism (Holmes, 1998), analysis gives evidence that the number of negative politeness strategies is significantly higher than that of female teenagers. As table 3 shows (see above), British and Spanish male teenagers exploit one main negative politeness strategy; that is, they minimise the imposition by giving deference, and/or apologising. Consider the following examples:

(36) Male, 17 years old, Spanish

"Qué pasa Señor! Le importa si en vez de irnos a "la penúltima" vamos al "Tómate 2+” He quedado con dos chochitos ricos y uno es pa ti ;)”

"What's up, Mister! Would you mind if we don't go to "la penúltima" and instead go to

"Tómate 2+" ? I'm meeting two chicks and one is for you ;)" 
(37) Male, 16 years old, British 'I'm really sorry but I'm not going to be able to make training tomorrow. Just wondering what's happening with spectating for Wednesday? I would love to come along and support you all"

(38) Male, 17 years old, Spanish

"Tio lo siento de veras pero es que no puedo ver el partido hoy. No te chines y hablamos mañana"

"Mate, I'm really sorry but I can't go and watch the match with you today. Don't get angry and talk to you later"

Taken together, these examples suggest that these negative politeness strategies seem to aim at building in-group solidarity and strengthening the bonds of friendship. this particular linguistic strategy was not identified when both these British and Spanish male teenagers were commenting on their female friends' Facebook walls.

\section{CONCLUSION}

The present study purports to shed light on how gender is constructed discursively and performed. This analysis of Facebook posts has demonstrated how these British and Spanish male and female teenagers perform their gendered identity when socializing with their Facebook friends.

In addition, a detailed analysis of the online topics these teenagers discussed has shown that topicality still revolves around old traditional patriarchal stereotypes: sports and sex for the males vs love relationships and gossip for the females. Using content area analysis, a thorough investigation of politeness strategies in these two most frequent topics has been carried out. The analysis punctures the myth that female teenagers exploit far more positive and negative strategies than male teenagers. The study shows how both British and Spanish male and female teenagers use a similar number of positive politeness strategies in an attempt to evaluate themselves and others. Of particular interest is the claim of the presence of online compliments made both by male and female teenagers indistinctly. Finally, the analysis has suggested that British and Spanish male teenagers use a higher number of negative politeness strategies. In particular, male teenagers seem to use this linguistic strategy in online interpersonal communication to build rapport and establish a relationship bond. 


\section{REFERENCES}

Brown, P. and S. Levinson. 1987. Politeness: Some universals in language usage. Cambridge: Cambridge University Press.

ButLer, J. 1990. Gender Trouble: Feminism and the Subversion of Identity. New York and London: Routledge.

CAMERON, D. 1995. "Rethinking language and gender studies: some issues for the 1990's." Language and Gender: Interdisciplinary Perspectives. ED. S. MilLs. London: Longman. 31- 44.

CAmERon, D. 1998. “Gender, Language, and Discourse: A Review Essay.” Signs: Journal of Women in Culture and Society 23: 945-67.

Cammack, J.C. and P.D. Kalmbach. 2002. "Discourses and Subjectivities of the Gendered Teacher." Gender and Education 14 (2): 123-135.

Christie, C. 2002. "Politeness and the Linguistic Construction of Gender in Parliament: An Analysis of Transgressions and Apology Behaviour." Sheffield Hallam Working Papers on the Web: Linguistic Politeness and Context. Retrieved from http://www. shu.ac.uk/wpw/politeness/christie.htm.

CoATes, J. 2004. Women, Men and Language: A Sociolinguistic Account of Sex Differences in Language. London and New York: Longman.

Crawford, M. 1995. Talking Difference: On Gender and Language. London: Sage.

Dellasega, C. and C, Nixon. 2003. Girl Wars: 12 Strategies That Will End Female Bullying. Simon and Schuster: New York.

ECKERT, P. 1989. "The whole woman: sex and gender differences in variation." Language Variation and Change (1): 245-267.

2000. Linguistic Variation as Social Practice. Oxford: Blackwell.

Eelen, G. 2001. A Critique of Politeness Theories. Manchester: St Jerome Publishing.

EgGins, S. and D. Slade. 1997. Analysing Casual Conversation. London: Cassel.

Esopo, R. 2010. "Lenguaje y sexo. Diferencias lingüísticas entre hombres y mujeres." Retrieved from http://www.blogolengua.com/2010/05/lenguaje-y-sexo-diferencias-entre.html

Foley, W. 1997. Anthropological Linguistics. An introduction. London: Blackwell

Fraser, B. 1990. “Perspectives on politeness.” Journal of Pragmatics 14: 219-236.

GARCíA-GómEZ,A. 2006. "British and American expressions of politeness in anger-evoking contexts: a cultural-relativistic approach." Culture, Language and Representation 3: $145-159$.

2008a. "Gender on the screen: a public view of private writing." Clepsydra: revista de estudios de género y de teoría feminista 7: 89-117. 
2008b. "Laddish behaviour and gender performativity in British and Spanish personal weblogs." English studies 29: 43-69.

2010. "Competing narratives, gender and threaded identity in cyberspace." Journal of Gender Studies 19 (1): 27-42.

2013. "Rethinking agency: Pornified discourses and shifting gendered subjectivities." Eds. B. GOSS and C. CHAVEZ. Identity Beyond Tradition and McWorld Neoliberalism. Newcastle upon Tyne: Cambridge Scholars.191-214.

2014. "Deconstructing 'mean girls': Impolite verbal behaviours, on/offline self- representations and evaluative beliefs." Eds. A. SÁnchez MacArro and A.B. Cabrejas. New Insights into Gender. Discursive Practices: Language, Gender and Identity Construction. English in the World Series. Valencia: Universitat de Valencia. 73-99.

Giroux, H. A. 2005. Schooling and the struggle for public life: Democracy's promise and education's challenge. Boulder, CO: Paradigm Publishers.

Holmes, J. 1986. "Compliments and compliment responses in New Zealand English." Anthopological Linguistics 28, 4: 485-508.

Holmes, J. 1995. Women, men and politeness. London: Longman.

1998 “Women's Talk: The Question of Sociolinguistic Universals.” ED. J.CoATES. Language and Gender: A Reader. Oxford: Oxford University Press. 461-483.

Holtgraves, T. M. 2002. Language as social action: Social psychology and language use. Mahwah, NJ: Erlbaum.

Humm, M. 1989. Feminist Criticism. Brighton, Sussex, Great Britain: Harvester Press.

JansSEn, A. and T. Murachver. 2004. "The relation between gender and topic in gender-preferential language use." Written Communication 21: 344 - 367.

Johnson, S. and U. MeInhooff. 1997. Language and Masculinity. Oxford \& Cambridge, MA: Blackwell.

Johnson, D. M. and D.H. Roen. 1992. "Complimenting and involvement in peer reviewers: Gender variation." Language in Society 21: 27-57.

Knapp, M. L., R. Hopper and R.A. Bell. 1984. "Compliments: A descriptive taxonomy." Journal of Communication 34, 4: 12-32.

Labov, W. 1972. Sociolinguistic patterns. Philadelphia: University of Pennsylvania.

Lakoff, R. 1975. Language and Women's Place. New York: Harper \& Row.

Leech, G. N. 1983. Principles of Pragmatics. London: Longman.

LOCHER, M. and J. Watts. 2005. "Politeness theory and relational work." Journal of Politeness Research 1, 1: 9-33.

Maíz-ArÉvalo, C. 2010a. "Intercultural Pragmatics: a contrastive analysis of compliments in English and Spanish.” Eds. M. L. Blanco Gómez and J. Marín Arrese. 
Discourse and Communication: Cognitive and Functional Perspectives. Madrid: Dykinson \& Universidad Rey Juan Carlos. 175-208.

2010b. "Evaluating the other: Analysis of computer-mediated compliments in English and Spanish." Web-poster presented at the 4th International Conference of Intercultural Pragmatics (Madrid, October 2010). Available at: http://conference. clancorpus.net $/ \mathrm{p}=493$

2012a. "At a loss for words or how to respond to compliments: A contrastive analysis of compliment response in English and Spanish." Eds. L. Fernández AmAya, M. O. Hernández, R. Gómez Morón, M. Padilla Cruz, M. Mejías Borrero, and M. Relinque Barranca. (Im)Politeness and Interpersonal Communication. Newcastle-upon Tyne: Cambridge Scholars. 157-163.

2012b. "'Was that a compliment?' Implicit compliments in English and Spanish.” Journal of Pragmatics 44, 8: 980-996.

Mills, S. 2003. Gender and Politeness. Cambridge: Cambridge University Press.

Peck, J. 2006. "Women and Promotion: The Influence of Communication Style." Ed. M. Barrett and M. Davidson. Gender and Communication at Work. Hampshire: Ashgate. 50-66.

Pilkington, J. 1998. “'Don't try and make out that I'm nice!' The different strategies women and men use when gossiping." Ed. J. COATES. Language and Gender: A Reader. Blackwell: Oxford. 254-269.

Ringrose, J., L. Harvey, R. Gill And S. Livingstone. 2013. "Teen girls, sexual double standards and 'sexting': Gendered value in digital image Exchange." Feminist Theory 14, 3: 305-323.

Ríos GonzÁLEz, G. 2007. "Diferencias léxicas entre el hombre y la mujer en tres centros de interés: Saludos, Temas de conversación y Despedidas." Revista de Filología y Lingüística XXXIII, 1: 151-166.

SCOllon, R. 2001. "Interpersonal politeness and power." Eds. R. SCOLlon and S. SCOLLON. Intercultural communication: a discourse approach. Oxford: Blackwell. 43-59.

SPEer, S. A. 2005. Gender Talk: feminism, discourse and conversation analysis. London and New York: Routledge.

Swann, J. 2002. “'Yes, but is it gender?"” Eds. L. Litosseliti and J. SunderLand. Gender Identity and Discourse Analysis. Amsterdam: John Benjamins. 43-67.

Tannen, D. 1990. You just don't understand. New York: William Morrow. 1995. Gender and discourse. Oxford: Oxford University Press.

West, C. and D.H.Zimmerman. 1983. "Doing gender.” Gender and Society 1: 125-151. 
Wolfson, N. 1983. "An empirically based analysis of complimenting in American English.” Eds. N. WolfSON and E. JUdD. Sociolinguistics and Language Acquisition. Tokyo: Newbury House Publishers. 82-95.

Yule, G. 1996. Pragmatics. Oxford: Oxford University Press 